\title{
Examination of Attitude Levels of Academic Personnel Towards Political Participation and Determination of Its Relationships with Organizational Commitment
}

\author{
Ersan Tolukan ${ }^{1} \&$ Yakup Akyel $^{2}$ \\ ${ }^{1}$ Faculty of Health Sciences, Ankara Yıldırım Beyazıt University, Turkey \\ ${ }^{2}$ Faculty of Education, Ahi Evran University, Turkey \\ Correspondence: Ersan Tolukan, Department of Sport Sciences, Faculty of Health Sciences, Ankara Yildırım \\ Beyazit University, Ankara, 06010, Turkey. E-mail: ersantolukan@gmail.com
}

Received: February 2, 2019

Accepted: March 5, 2019 Online Published: March 8, 2019

doi:10.5539/jel.v8n2p231

URL: https://doi.org/10.5539/jel.v8n2p231

\begin{abstract}
The aim of this study was to determine the attitudes of academic personnel working in faculties of sports sciences in universities towards political participation; to examine whether there was a significant difference between the attitudes of academicians towards political participation according to demographic characteristics; to determine the relationships between academic personnel's attitudes towards political participation and their organizational commitment. The study, which was designed in the correlational survey model of the general survey models, was carried out together with 204 academicians working in universities in Central Anatolia Region. The data of the study were collected by means of using the Political Participation Scale and Organizational Commitment Scale. Descriptive statistics, difference tests and Pearson correlation coefficient were used in the process of data analysis. At the result of the research, it was determined that the feelings of political activity and the feelings of alienation of academic personnel as well as their political perceptions arising from the institution were generally at a medium level. It was determined that there was a positive relationship between the feelings of political activity and the dimensions of organizational commitment of academicians.
\end{abstract}

Keywords: political participation, organizational commitment, sport sciences, academic personnel

\section{Introduction}

According to the majority of political scientists, politics is the science of state; and according to some of them, politics is the science of power (Eroğlu, 2015). If politics is always considered as an activity appealing to state, then it's clear that involvement in state government will have the same meaning with political participation. In contrast, if politics is regarded as a power relation regardless of its conceptual framework in which it forms itself, then the participation in state and government and political participation will inevitably have different meanings (Gülmez, 1995). According to the latter understanding, in each institution with a relationship between the commanding and submitting parties, that is, a syndicate, an association, school, religious organization, Professional establishment or even in a family and if there is a struggle for power, then political participation will include all these fields as well as the state (Eroğlu, 2015). Therefore, the concept of power might lay the basis for politics, however, it's the 'political government' which is mentioned in political participation not all types of power. In this sense, it is more realistic to consider political participation as getting involved in 'state', which is the umbrella of all institutions, government.

Undoubtedly, in a political system, individuals need to demonstrate certain processes in the political system so that they can play certain political roles, become a 'political person' equipped with certain values, beliefs and tendencies, or to win 'political self' (Dursun, 2004) and a neutral individual who exhibits indifferent or spectator behavior who does not participate in the political processes, has no political effect if he has no connection with the political environment and is not involved in any decision-making mechanism. Such individuals think that their actions do not have any political consequences. However, this ordinary, faint, asocial individual will also have a certain political effect in the particular conjuncture. In fact, these asocial and apolitical individuals play an important role in the formation of what is called public opinion to the extent that they are directed. Some individuals carry out a motive, repulsive function in the formation of public opinion, while others advocate their 
pre-formed views because everyone supports them and they do not have arguments or courage to defend the opposite (Çağla, 2015). In this context, in a political society, individuals need to be aware of the fact that the functioning of the political system will directly or indirectly affect their own situation in order to play political roles and act in political behaviors, and that the decisions taken by the political power and the rules that it will govern will have an impact on their future. If the roles they play and the behaviors and actions they put forward will have no effect on the political process and the functioning of the system, it is unthinkable for individuals to take various actions on the political system in this environment.

Given these explanations, this study considers that the basic approach is that individuals participate in the political process, even if they are at various levels, or act consciously, and take their attitudes and behaviors against the political system as participation activities. In this context, the aim of this study is to determine the attitudes of academic staff working in faculties of sports sciences in universities towards political participation; to examine whether there is a significant difference between the attitudes of academicians towards political participation according to demographic characteristics; to determine the relationships between academic staff's attitudes towards political participation and their organizational commitment.

\subsection{Political Participation, Political Activity and Alienation from Political Process}

In systems where participation mechanisms work well, politics is not an action for individuals, but an action taken by them. Acting is its greatest virtue, and interest, commitment, obligation and service, common negotiation, joint decision and collaborative work are distinctive features (Barber, 1995). As it is known, it is difficult to say that a form of government where the individual feels himself worthless and powerless, and is not a perpetrator, intersects with democracy. In this sense, the most important guarantee of democracy is individuals. The strong democracy in the form of a participant paves the way for the formation of a political society that can turn dependent individuals into free citizens and private interests into public interests in the process of creating their own laws (Barber, 1995).

A democratic system based on participatory society or intense participation is built on the concept of citizenship. The building blocks of a democratic society are individuals who perceive politics as a way of life and who do not see politics as an act of politicians. Therefore, participation is not a problem with the political system, but rather a problem with the individual. The individual is as good or qualified to the extent that he/she participates in these processes. Participation is also an important criterion and indicator of being a citizen. Participatory behavior is an action that explains the relationship between the individual and the political system. Therefore, the content of participation varies according to the size of the relationship between the individual and the political system. This situation was used as a criterion in the history of democracy in all democracy, as a criterion showing the link between the individual and the political system. One dimension of democratic system is related to values and institutions. Robert Dahl divides the dimensions of political participation into four as "paying attention", "caring", "getting informed" and "taking action" (Dahl, 1963). The most advanced dimension of participation is to act. However, since participation in certain systems is limited to elections, effective participation is not widely available. In this respect, making the political system open to an active, continuous and dynamic participation will provide a situation that encourages individuals in terms of political participation.

These features are a realization of a change in the consciousness of the individuals required for real participation; they need to see themselves actively, and try to increase and develop their capacities. Therefore, the individual can only act in a way that he/she feels free and develops himself/herself in the real sense (Saribay, 2000). This participation may simply be as an individual or may be in a group with that group. The discussions on this issue are basically on two issues; the value of political participation for the individual and the political system and the reasons for participating or not participating (Çağla, 2015). It is closely related to the functionality of the mechanisms that will enable individuals to participate effectively in all the decisions that affect them and that this participation takes place at a very high rate in all sectors of the society (Olsen, 1982). To be able to talk about participation in the real sense, all individuals should have the opportunity to participate in the collective decision-making to the extent that they desire to take all collective decisions, and participation in collective decision-making should not be limited to voting, but should also cover a wide range of activities (Huntington \& Dominguez, 1986). In addition, the responsibility for collective decision-making must be broadly distributed, should not be limited solely to officials and/or experts, include all persons affected by these decisions, and in particular to participate in collective decisions in non-political areas, to teach individuals political skills and norms, and to encourage them to participate in broader political issues (Saribay, 2000).

The differences in the society in which individuals are born are signs of political participation. In addition, the individual's interest in politics and personality structure, the approach to social, political and economic problems, 
the structure of the political system-democratic or totalitarianism, social culture-tradition, religion, ideology, morality and socio-economic-level-development, underdevelopment-characteristics that influence political participation and differ from one society to another. Naturally, it is wrong to reduce political attitudes to political participation only when the individual affects society or society is shaping the individual; individuals take a role in political society and institutions deliberately and their attitudes towards political problems are shaped within the homogenous social mixture, and one of the various aspects of this mix may prevail.

Undoubtedly, every political system wants to instill knowledge, thought, rule, belief and value in order to adapt its members to their values and principles. Individuals respond to this demand, either positively or negatively (Dahl \& Stinebrickener, 2003). The power that holds the political system; through ideological, structural, and personal resources, individuals feed their consent to their power (Eckstein, 1988). It utilizes ideological tools such as propaganda, education and economic relations; structural tools such as law, bureaucracy; personal traits like heroism and leadership thus seeking "widespread support" for the emergence of individuals who faithfully adhere to the board order using personal tools (Erickson \& Romero, 1990). The executive power nourishes the people's choice and demand areas with these resources in order to nourish their self-directed social support. This relationship is the reciprocal feeding relationship, which can be based on this demand and support relationship.

As long as the organizational commitment of the individual are promoted depending on ideological, legal and economic factors towards the political system and institutions, the institutional supports of the system become stronger and a harmonious correlation process is launched between the individual and the system/institution. The individual finds his/her role in the institution and in the political system. Political and institutional structure also prepares the individual for that role. The individual functions in the role of both the environmental siege and the ideological siege of the political system. In this way, the continuation of the political and institutional system in unchanged constant basic principles is guaranteed (Evans, 2004). In this context, the main object of the individual to be politicized to accept his role, the system to support the individual to play this role. Through these mutual supports, the continuity of the legitimacy of the political and institutional system will be ensured. However, the individual, social and political changes of the political, institutional and organizational structure and the fact that the individual ignores the demand for role other than the given roles directed at him/herself is an important problem. This situation may cause the emergence of a feeling of alienation in individuals (Friedrich, 1998). The individual does not want to abide by the organizational and institutional structure established by the influence of the socio-economic class, the social status group, the ethnic and religious structure, and the ideological environment. With the contribution of these interactive elements, it can follow a confrontational attitude against different formations or try to stay away from the system. In fact, they can develop behavior towards them by not adopting the values and principles of the established order (Gassett, 1991).

As a result, the sense of activity that an individual carries in political participation as an action and behavior is generally one of the variables that affect the participation in a stimulating way, while the sense of alienation is one that affects the attenuating and decreasing participation. The sense of activity is a belief and attitude that an individual can change his/her environment through his/her own actions and behaviors, and that he/she can influence, control the environment and organize his future with his/her behaviors.

The individual with such a belief and attitude will be able to participate more easily in political life, as well as being interested in all kinds of developments and not hesitating to participate in political processes. On the other hand, the sense of alienation may reveal feelings of experience or experiential loss that the individual is unable to control the existing organizational structures from the values, rules, expectations and relations, and that the possibility of controlling these processes from the individual perspective disappears. It is a situation in which the system or institutional organization does not make sense for the individual and does not respond to the real needs and prevents the individual from realizing himself/herself, which is the situation of the individual breaking away from the system (Çetin, 2012; Kubat \& Şentürk, 2018). Hence, the sense of alienation hinders political participation as a negative factor that pushes the individual out of the system and breaks the whole relationship.

The main purpose of this study was to investigate the attitudes of academicians working in the Faculties of Sport Sciences according to various variables and to determine the relation between them and organizational commitment. Political participation and alienation, with a concentration in Turkey subject areas covered in the private sector working level, much has not been studied in universities. In this sense, the specificity and importance of the study is increasing.

\section{Method}

\subsection{Research Model}

In this study, it was aimed to determine the attitudes of academic staff working in the faculty of sports sciences 
in universities towards political participation and to analyze their attitudes towards political participation on the basis of demographic characteristics. In the scope of the research, the relations between academic staff's attitudes towards political participation and their organizational commitment were also examined. In this respect, the research was designed in the relational survey model from the general survey model of quantitative research methods. The general screening model was a quantitative description of the characteristics of the sample included in the study (Creswell, 2016). In the relational survey model, correlations between the opinions, attitudes or tendencies of a group are calculated and relationships were determined. In this respect, research was also called as correlation research (Büyüköztürk et al., 2017).

\subsection{Population and Sample}

The population of the study consists of 407 academicians working in the sports sciences faculties of the universities in the Central Anatolia Region during the 2017-2018 academic year. In the sample selection, the number of persons who will represent the universe was determined and the following equity proposed by Büyüköztürk et al. (2017) was used.

$$
n=\frac{n_{0}}{1+\frac{n_{0}}{407}}
$$

Equaty 2.1. Prediction of population magnitude in constant variables

It was calculated by using the Equity 2.1. $\mathrm{n}_{0}=\left(\mathrm{t}^{2} \mathrm{PQ}\right) / \mathrm{d}^{2}$ and when $\mathrm{p}$ significance value was taken as 0.05 , then $\mathrm{pq}=0.25$ and the corresponding $\mathrm{t}$ value in the Table will be $1.96, \mathrm{n} \_0=384.16$ is calculated at 0.05 significance level (Büyüköztürk et al., 2017, p. 98). In this direction, it was determined that 407 academicians in the population would be represented by at least 198 academicians. After determining the number of samples, the sample selection was made from the population based on stratified sampling method. First of all, universities and academic staff were listed. On the basis of volunteerism from different universities, individuals were included in the study. $1.5 \%$ of participants comprise of $(n=3)$ professors, $8.3 \%(n=17)$ Associate Professors, $34.3 \%(n=70)$ Phd. Lecturer, 9.3\% $(n=19)$ Phd. Instructor, 27.0\% $(n=55)$ Instructors, 3.4\% $(n=7)$ Phd. Research Assistants and $16.2 \%$ of them are $(\mathrm{n}=33)$ Research Assistants.

\subsection{Data Collection Tools}

The data of this study were collected with Attitude Scale for Political Participation and Organizational Commitment Scale. In order to determine the attitudes of academicians towards political participation by Sahin (2013), there were 21 items in three dimensions. The scale items were rated in 5-point Likert Scale.

The items prepared in the development process of the scale were applied to 176 academicians working at the School of Physical Education and Sports. In order to determine the construct validity of the scale in accordance with the answers obtained from academicians, exploratory factor analysis was calculated. After the analysis, it was determined that the substances were collected in three dimensions. The factor loadings of the first dimension, called the sense of political activity, vary between 0.40 and 0.76 ; the load values of the second-dimension substances, called the sense of alienation, were between 0.60 and 0.78 ; factor loadings of the third dimension, which was called as political perception from the institution, were found to vary between 0.51 and 0.84 . It was determined that the items in the scale clarified $51.29 \%$ of the total variance. The Cronbach Alpha coefficient was calculated to determine the reliability of the responses to the scale items. The coefficient was 0.71 for the first dimension; 0.67 for the second dimension; the third dimension was calculated as 0.89 (Şahin, 2013).

The Cronbach alpha reliability coefficient was calculated in order to determine the reliability of the responses of 204 academic staff to the scale items. The coefficient is 0.733 for a sense of political activity; 0.647 for a sense of alienation; 0.890 for the political perception arising from the institution. The calculated values indicate that the academic staff participating in the study responded to the scale items reliably.

Organizational Commitment Scale; in order to determine the organizational commitment of academic staff, the scale developed by Meyer and Allen (1997) was first performed by Wasti (2000) in a validity and reliability study (emotional commitment 0.79 , normative commitment 0.75 and continuation commitment 0.58 ) (Vasti, 2000) and later adapted to Turkish by a large number of researchers. As a result of the validity and reliability study conducted by Başol and Yalçın (2009) in education organizations, Cronbach alpha internal consistency coefficient for the emotional attachment factor was identified as .84 , normative commitment as .81 , and continuity commitment as .63 (Başol \& Yalçın, 2009).

The scale was also applied by Koç (2018) to faculty members working at the faculties of sports sciences. As a 
result of the calculation, it was determined that the scale items were collected in three dimensions and clarified $59.343 \%$ of the total variance and Cronbach alpha reliability coefficient was calculated as 0.801 .0 .925 for the emotional commitment dimension; The Cronbach coefficient for the continuation commitment was 0.675 and the normative commitment was 0.703 (Koç, 2018). In addition, Aytaç (2017) has reported that academic staff responds reliably to scale items with a value of 0.680 (Aytaç, 2017).

The Cronbach alpha coefficient was calculated to determine the reliability of the responses of 204 academic staff to the scale items. The coefficient was 0.933 for emotional commitment; continued adherence size for 0.660 ; 0.707 for normative commitment; and 0.795 for the whole scale. The calculated values indicate that academic staff responds reliably to scale items.

\subsection{Data Analysis}

In the process of data analysis, first of all, missing and extreme value analyses were conducted. After the missing and extreme value observations were excluded from the data set, the distribution of opinions of 204 academic staff was examined. In this direction, firstly skewness and kurtosis coefficient were calculated and the results were shown in Table 1.

Table 1. Skewness and Kurtosis coefficients

\begin{tabular}{llll}
\hline Scale minimal dimensions & N & Skewness & Kurtosis \\
\hline Feeling of Political Activity & 204 & -0.218 & -0.325 \\
Feeling of Alienation & 204 & 0.169 & -0.314 \\
Political Perception Arising from the Institution & 204 & -0.234 & -0.431 \\
\hline
\end{tabular}

As shown in Table 1, it was determined that the skewness and kurtosis coefficients of the scores of the academic staff attending the research were lower than \pm 1 . In this direction, it can be said that the scores obtained from the sub-dimensions do not show an extreme deviation from the normal.

In order to determine the distribution of the points, histograms were also used and the results are shown in Figure 1.

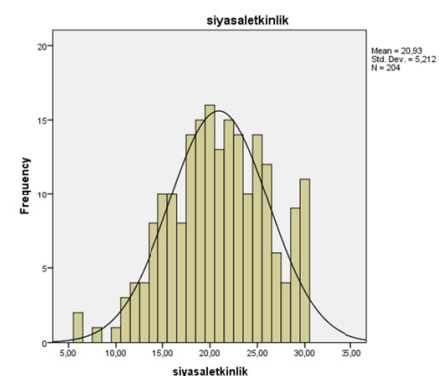

Feeling of Political Activity

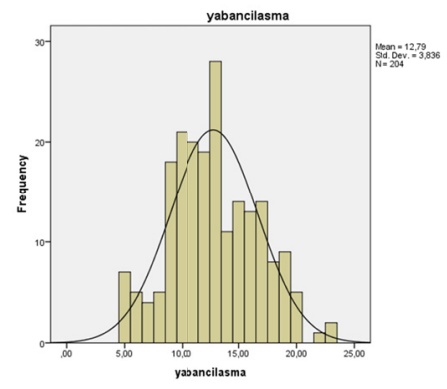

Feeling of Alienation

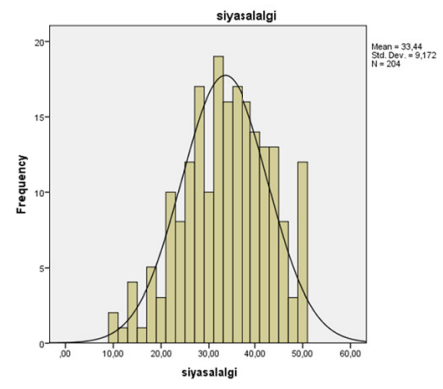

Political Perception Arising

From Institution

Figure 1. Histogram graph generated for point distributions

As it can be seen in Figure 1, it was found that the scores of the academicians related to the sub-dimensions in the attitude scale towards political participation demonstrated normal distribution.

Descriptive statistics were calculated in the process of analyzing the data. Then, the distribution of data sets and variances were found to be homogeneous in each variable category. In this respect, parametric statistics were calculated and t-test and one-way analysis of variance was used for unrelated measurements. The significance of the results was accepted as 0.05 . The Pearson correlation coefficient was also calculated to determine the relationships between the attitudes of the academic staff participating in the research and their organizational commitment to political participation.

\section{Results}

In this section, the findings of the research were given in accordance with the sub-problems. 


\subsection{What Are the Attitudes of Academic Staff Towards Political Participation?}

Table 2. Descriptive statistics of academic staff about attitudes towards political participation

\begin{tabular}{llllll}
\hline Sub-Dimensions of Scale & N & Lowest & Highest & $\bar{X}$ & SS \\
\hline Sense of Political Activity & 204 & 6.00 & 30.00 & 20.93 & 5.21 \\
Sense of Alienation & 204 & 5.00 & 23.00 & 12.79 & 3.84 \\
Political Perception Arising from Institution & 204 & 10.00 & 50.00 & 33.44 & 9.17 \\
\hline
\end{tabular}

When the information in Table 2 was examined, the average of the scores of political activity of the academic staff whose opinions were taken within the scope of the research was 20.93, the average of the points of political alienation was 12.79 , and the political perception scores originating from the institution; the average was calculated as 33.44 .

As the number of items in the scale of attitudes towards political participation is different, the average score from each subscale is divided by the number of items and the results are shown in Table 3.

Table 3. Descriptive statistics calculated by item

\begin{tabular}{llll}
\hline Sub-Dimensions of Scale & Number of Factors & $\overline{\mathrm{X}}$ & Factor Average \\
\hline Sense of Political Activity & 6 & 20.93 & 3.5 \\
Sense of Alienation & 5 & 12.79 & 2.6 \\
Political Perception Arising from Institution & 10 & 33.44 & 3.3 \\
\hline
\end{tabular}

It was determined that the academic perceptions of the academic staff who participated in the research were above the medium level and their attitudes towards alienation dimension were below the medium level. When the scale sub-dimensions were evaluated within itself, it was seen that the highest score of the academic staff belongs to the sense of political activity and the least score to the feeling of alienation.

3.2 Are the Attitudes of Academic Staff Towards Political Participation Differ Significantly According to Their Demographic Characteristics?

It was analyzed whether the attitudes of the academic staff according to their age and marital status showed a significant difference.

Table 4. T test results of unrelated measurements calculated regarding attitudes of academic staff towards political participation according to their age

\begin{tabular}{llllllll}
\hline Sub-Dimensions of Scale & Age & $\mathrm{N}$ & $\overline{\mathrm{X}}$ & $\mathrm{S}_{\mathrm{x}}$ & $\mathrm{sd}$ & $\mathrm{F}$ & $\mathrm{p}$ \\
\hline Sense of Political Activity & $21-35$ age & 80 & 20.48 & 5.27 & $2(203)$ & 0.507 & 0.603 \\
& 36-45 age & 91 & 21.20 & 5.16 & & & \\
Sense of Alienation & 46 and over & 33 & 21.30 & 5.30 & & & \\
& $21-35$ age & 80 & 13.05 & 4.07 & $2(203)$ & 0.708 & 0.494 \\
& 36-45 age & 91 & 12.44 & 3.55 & & & \\
Political Perception Arising from Institution & 46 and over & 33 & 13.15 & 4.04 & & & \\
& 21-35 age & 80 & 33.48 & 8.41 & $2(203)$ & 0.314 & 0.731 \\
& 36-45 age & 91 & 33.81 & 10.09 & & & \\
\hline
\end{tabular}

Note. ${ }^{*} \mathrm{p}<0.05$.

As can be seen in Table 4, the sense of political activity in academic staff participating in the research does not indicate a significant difference at $(\mathrm{F}(2.203)=0.507 ; \mathrm{p}>0.05)$, sense of alienation at $(\mathrm{F}(2.203)=0.708 ; \mathrm{p}>0.05)$ and political perception arising from the institution at $(\mathrm{F}(2.203)=0.314 ; \mathrm{p}>0.05)$. 
Table 5. $\mathrm{T}$ test results in unrelated measurements calculated for attitudes towards political participation based on the marital status of academic staff

\begin{tabular}{llllllll}
\hline Sub-Dimensions of Scale & Marital Status & $\mathrm{N}$ & $\overline{\mathrm{X}}$ & $\mathrm{S}$ & $\mathrm{sd}$ & $\mathrm{t}$ & $\mathrm{p}$ \\
\hline Sense of Political Activity & Married & 162 & 21.17 & 5.27 & 202 & 1.268 & 0.206 \\
& Single & 42 & 20.02 & 4.95 & & & \\
\multirow{3}{*}{ Sense of Alienation } & Married & 162 & 12.74 & 3.82 & 202 & 0.389 & 0.697 \\
& Single & 42 & 13.00 & 3.94 & & & \\
Political Perception Arising from Institution & Married & 162 & 33.96 & 9.23 & 202 & 1.602 & 0.111 \\
& Single & 42 & 31.43 & 8.76 & & & \\
\hline
\end{tabular}

Note. ${ }^{*} \mathrm{p}<0.05$.

Given the data in Table 5, the sense of political activity of the academic staff $(\mathrm{t}(202)=1.268 ; \mathrm{p}>0.05)$, the sense of alienation $(\mathrm{t}(202)=0.389 ; \mathrm{p}>0.05)$ and the political perception originating from the institution $(\mathrm{t}(202)=1.602$; $\mathrm{p}>0.05$ ) did not show a significant change according to their marital status.

\subsection{What Is the Relationship Between the Attitudes of Academic Staff Towards Political Participation and Their} Organizational Commitment?

It was analyzed whether the attitudes of the academic staff according to their age and marital status showed a significant difference.

Table 6. Results of Pearson correlation coefficient calculated for the relationship between academic staff's attitudes towards political participation and their organizational commitment

\begin{tabular}{llllllll}
\hline Scales & Values & Alienation & $\begin{array}{l}\text { Institution } \\
\text { Based } \\
\text { Perception }\end{array}$ & $\begin{array}{l}\text { Emotional } \\
\text { Commitment }\end{array}$ & $\begin{array}{l}\text { Commitment to } \\
\text { Attend }\end{array}$ & $\begin{array}{l}\text { Normative } \\
\text { Comm. }\end{array}$ & $\begin{array}{l}\text { Organizational } \\
\text { Commitment }\end{array}$ \\
\hline Political Activity & $\mathrm{r}$ & $-.315^{* *}$ & $.288^{* *}$ & $.862^{* *}$ & $.798^{* *}$ & $.717^{* *}$ & $.804^{* *}$ \\
& $\mathrm{p}$ & .000 & .000 & .000 & .000 & .000 & .000 \\
Alienation & $\mathrm{r}$ & 1 & $.251^{* *}$ & $-.253^{* *}$ & $-.242^{* *}$ & $-.212^{* *}$ & $-.268^{* *}$ \\
& $\mathrm{p}$ & & .000 & .000 & .000 & .002 & .000 \\
Institution Based & $\mathrm{r}$ & & 1 & $.269^{* *}$ & $.211^{* *}$ & $.224^{* *}$ & $.269^{* *}$ \\
Perception & $\mathrm{p}$ & & & .000 & .002 & .001 & .000 \\
Emotional & $\mathrm{r}$ & & & 1 & $.699^{* *}$ & $.674^{* *}$ & $.913^{* *}$ \\
Commitment & $\mathrm{p}$ & & & & .000 & .000 & .000 \\
Commitment to & $\mathrm{r}$ & & & & 1 & $.619^{* *}$ & $.871^{* *}$ \\
Attend & $\mathrm{p}$ & & & & & .000 & .000 \\
Normative Comm. & $\mathrm{r}$ & & & & & 1 & $.857^{* *}$ \\
& $\mathrm{p}$ & & & & & .000 \\
\hline
\end{tabular}

Note. ${ }^{*} \mathrm{p}<0.01 ;{ }^{*} \mathrm{p}<0.05 ; \mathrm{N}=204$.

Given the data indicated in Table 6, there was a negative but minor level of correlation between the academic effectiveness and emotional commitment of the teaching staff participating the research $(r=0.862 ; \mathrm{p}<0.01)$, the continuity of commitment $(\mathrm{r}=0.798 ; \mathrm{p}<0.05)$, normative commitment $(\mathrm{r}=0.717 ; \mathrm{p}<0.01)$ and organizational commitment $(\mathrm{r}=0.804 ; \mathrm{p}<0.01)$, emotional commitment $(\mathrm{r}=-0.253 ; \mathrm{p}<0.01)$, continuity of commitment $(\mathrm{r}=-0.242$; $\mathrm{p}<0.01)$, normative commitment and $(\mathrm{r}=-0,268 ; \mathrm{p}<0,01)$ academic alienation and organizational commitment. In addition, there was a correlation $(\mathrm{r}=0.269)$ between participants' political perceptions and emotional commitment to the institution $(\mathrm{r}=0.269 ; \mathrm{p}<0.01)$, commitment $(\mathrm{r}=0.211 ; \mathrm{p}<0.01)$, normative commitment $(\mathrm{r}=0.224 ; \mathrm{p}<0.01)$ and organizational commitment.

When the relationship between the sub-dimensions of the scales was examined; a negative and moderate relationship was found between the emotions of political activity and alienation $(\mathrm{r}=-0.315 ; \mathrm{p}<0.01)$.

\section{Discussion}

The aim of this study was to investigate the attitudes of academic staff working in the Faculties of Sports Sciences towards political participation and to determine the relationships between their organizational commitment and their organizational commitment.

First of all, descriptive statistics about the attitudes of academic staff towards political participation were calculated. It was determined that the academic perceptions of the academic staff who participated in the 
research were above the medium level and their attitudes towards alienation dimension were below the medium level. In terms of scale sub-dimensions, it was found that the political activity dimension was more dominant and the lowest score belonged to the alienation dimension (Table 2).

Based on these results, it can be stated that academicians have a different attitude and attitudes about their own actions, behaviors and knowledge that they can change their environment and influence the political course.

Moreover, the fact that the political alienation dimension is slightly below the middle level indicates that the academic system and the functioning of academics do not make sense for themselves and that these processes are subject to detachment from the political system due to lack of opportunity to influence such processes (Çetin, 2012). This result is very thought-provoking in the sample of academicians who are in the position of leading the society or providing alternative hypotheses.

According to the age and marital status of the academic staff included in the study, it was determined that there was no significant difference in political activity, political perceptions of the institution and political alienation sub-dimensions. In other words, age and marital status have no effect on political participation (Table 4-5).

According to the results of the correlation between the attitudes of academic staff towards political participation and their organizational commitment; it was observed that there was a positive and high-level relationship between the sense of political activity and the organizational commitment of the participants (Table 6).

While the political system of the organizations presents the resources and values from the top down in a commanding manner, the demands/expectations within the organization, on the other hand, are conveyed within these mandatory limits from the bottom up, within the procedures and the specified processes. Hence, participation is a mechanism that enables both individuals to integrate with organizational gains and values, and to affect individuals' organizations (Uysal, 1984). In this sense, as the attitudes of academicians towards political participation increase, the emotional, continuity and normative commitment of the institution tends to increase. Because political socialization shapes political behavior in the context of political events. In this respect, political participation is a process explaining the similarity and integration of the individuals with the political society. The nature, prevalence and direction of political participation is a situation which is expected to promote the organizational commitment as an impressive political participation considering that the institution they work in is limited by the boundaries drawn by the political system (Yolcu, 2017).

In addition, it was determined that there was a positively low-level relationship between the political perceptions of the academic staff participating in the study and their organizational commitment and their negative and low-level political perceptions and their organizational commitment.

When the attitudes of the Academicians towards Political Participation Scale with their sub-dimensions are examined; it was found that there was a negative and moderate relationship between the emotions of political activity and the feelings of alienation. In other words, as political alienation increases, participation in political activities decreases (Table 6). Undoubtedly, political behavior cannot be expected from a person who is severed from the system because this situation will appear as a lack of interest in the political phenomenon and will remove it from political behavior (Turan, 1991). As an action and behavior, the individual's sense of activity and assertiveness in political participation generally affects the stimulus in a stimulating way, whereas the sense of alienation is an effect of reducing and attenuating participation (Caprara et al., 2007). The sense of activity is specifically important in political participation behavior. The sense that an individual can change and affect his/her environment through his/her own behaviors, enables the individual to exhibit more active behaviors in political life. It can be argued that individuals who do not refrain from taking part in the initiative are more likely to participate in political life (Dursun, 2004).

As a result, modern political democracy is a management system in which the rulers are held accountable by citizens for their actions in state affairs and the elected representatives act indirectly through competition and cooperation between them. In this respect, democracy is the dominant political doctrine of the contemporary world. By the same token, almost every country argues that its political regime is democratic (Kuzu, 1992). However, within the political history period, there has been a transformation from a limited democratic system based simply on voting from election to election towards a participatory democracy, which is defined as based on principles such as political participation, taking part in decision-making mechanisms, accountability in the process of implementation of policies and persuading people. Thus, with the increasing visibility of these social movements, boycotts, rallies or similar activities, which we call non-traditional participation, the interest of citizens in matters such as education, health and local services that affect them in daily life has increased and the tendency to participate in these activities. In this process, a new understanding, which accepts individuals as a partner of the public (stakeholder citizen) while not overlooking the citizenship bond of the individuals, has 
begun to gain ground gradually (Toksöz, 2008).

In this context, the transition to a participatory democracy, which is defined as political the "self-governance of the people", from a political regime that allows only the lowest level of political voting and participation in the elections, can be achieved through the high political participation and political socialization of individuals.

Based on this information, the right to political participation as a concession in public officials in Turkey and legal arrangements which holds the frame academicians' political participation, attitudes towards democracy, as well as their insights and reflections on relationships in their daily lives is of great importance in creating their own unique political culture of higher education institutions.

\section{References}

Aytaç, K. Y. (2017). Investigating the working life quality and organizational commitment behaviors of academicians carrying on duties in faculties of sports sciences. European Journal of Education Studies, 3(11), 603-628. https://doi.org/10.5281/zenodo.1069116

Barber, B. (1995). Güçlü Demokrasi (Edt. M. Beşikçi). İstanbul: Ayrıntı Publications.

Başol, G., \& Yalçın, B. (2009). Validity and reliability study of meyer and allen three-dimensional organizational commitment scale in educational organizations (pp. 497-507). 5th International Balkan Educational and Science Congress Full Text Book, Trakya University, Edirne, Turkey.

Büyüköztürk, Ş., Kılıç-Çakmak, E., Akgün, Ö. E., Karadeniz, Ş., \& Demirel, F. (2017). Scientific research method. Ankara: Pegem Akademy.

Caprara, G. V., Vecchione, M., Barbaranelli, C., \& Fraley R. C. (2007). When likeness goes with liking: The case of political preference. Political Psychology, 28(5), 609-632. https://doi.org/10.1111/j.1467-9221.2007.00592.x

Creswell, J. W. (2016). Araştırma deseni nitel, nicel ve karma yöntem yaklaşımları (Edt. Demir, S.B.). Ankara: Eğiten Book.

Çağla, C. (2015). Political science. İstanbul: Bilgi Kültür.

Çetin, H. (2012). Siyaset bilimi. Ankara: Orion Publisher.

Dahl, R. A. (1963). A preface to democratic theory. Chicago: University of Chicago Press.

Dahl, R. A., \& Stinebrickner, B. (2003). Modern political analysis. Englewood Cliffs: Prentice Hall, Inc.

Dursun, D. (2004). Political science. İstanbul: Beta Publications.

Eckstein, H. (1988). A culturalist theory of political change. The American Political Science Review, 82(3), 789804. https://doi.org/10.2307/1962491

Erickson, R. S., \& Romero, D. W. (1990). Candidate equilibrium and the behavioral model of the vote. American Political Science Review, 84, 1103-1125. https://doi.org/10.2307/1963255

Eroğlu, C. (2014). Siyaset bilimi. In G. Atılgan \& E. A. Aytekin (Eds.), Siyasal Katılma. İstanbul: Yordam Publisher.

Evans, J. A. J. (2004). Voters and voting: An Introduction. London: Sage Publications.

Friedrich, C. J. (1998). Authority. Cambridge: Harvard University Press.

Gassett, O. Y. (1991). The revolt of the masses. London: Allen and Unwin.

Gülmez, M. (1995). Officers unions and political activity. Journal of TODAI (Amme İdaresi), 28(2), 29-50.

Huntington, S. P., \& Dominiguez, I. (1986). Siyasal gelişme ve siyasal bozulma (Edt. Özbudun, E.). Ankara: Siyasi İlimler Derneği Publications.

Koç, M. (2018). Research on correlations between academicians' levels of organisational commitment and their intention to quit their job: a comparison of state and foundation universities. Journal of Education and Learning, 7(1), 163-173. https://doi.org/10.5539/jel.v7n1p163

Kubat, R., \& Şentürk, A. (2018). Physical education teachers organizational trust and organizational investigation of awareness levels. Uluslararası Rekreasyon ve Spor Bilimleri Dergisi, 2(1), 53-67. Retrieved from http://dergipark.gov.tr/ijrss/issue/41363/490994

Kuzu, B. (1992). Democracy - Historical Ideology - Civil Society. Ankara University Journal of SBF, 47(1), $335-369$. 
Meyer, J. P., \& Allen, N. J. (1997). Commitment in the workplace. Theory, Research and Application. London: Sage Publications.

Olsen, M. E. (1982). Participatory pluralism: Political participation in the United States and Sweden. Chicago: Nelson-Hall.

Sarıbay, A. Y. (2000). Global bir bakışla politik sosyoloji. İstanbul: Alfa.

Şahin, M. Y. (2013). Attitudes of academicians in schools of physical education and sports towards political participation: A relational study. Life Science Journal, 10(4), 556-564.

Toksöz, F. (2008). İyi yönetişim el kitabı. İstanbul: TESEV Publications.

Turan, İ. (1991). Siyasal sistem ve siyasal davranış. İstanbul: Der Publications.

Uysal, B. (1984). Impact of family on political participation behavior. Journal of TODAI (Amme İdaresi), 17(4), $109-134$.

Wasti, S. A. (2000). Reliability and validity analysis of Meyer and Allen's three-dimensional organizational commitment scale (pp. 401-410). 8. National Management and Organization Conference, Erciyes University.

Yolcu, N. (2017). The measurement of reliance for the political participation level and for the means of political socialisation: An empirical study on the province of Kocaeli. Journal of Erciyes Communication, 5(1), 40 58.

\section{Copyrights}

Copyright for this article is retained by the author, with first publication rights granted to the journal.

This is an open-access article distributed under the terms and conditions of the Creative Commons Attribution license (http://creativecommons.org/licenses/by/4.0/). 